\title{
Development And Motivation In/For Critical Thinking
}

\author{
Larry W. Riggs, Butler University, USA \\ Sandra Hellyer-Riggs, Indiana University-Purdue University Indianapolis, USA
}

\begin{abstract}
An explicit link between the issues of development and critical thinking is provided by Elder and Paul (1996). In their stage theory of critical thinking, Elder and Paul argued that the first stage beyond unreflective thinking is that of the challenged thinker. The challenged thinker is one who has become aware of the actual role of thinking in life and of significant problems caused by unreflective thinking. This is in accord with our experience, which we will describe and analyze in this article. History and contemporary society are saturated with and driven by thinking, much of which is developmentally immature and disastrous. Scriven and Paul (1987) made the crucial point that shoddy thinking is costly. Our approach to fostering critical thinking deals with the issue of motivation to think critically by focusing on the costs of not doing so. We agree with McPeck (1994) that some course content areas are more suitable than others for fostering critical thinking. In the courses we will describe here, we are able to challenge students to think about issues that have significant impact in the social world. Our goal is to move students to recognize that they can, and should, become critical thinkers and that recognizing meaningful challenges is the first developmental step.
\end{abstract}

Keywords: Critical Thinking; Unreflective Thinking; Motivation, Challenged Thinking; Development

\section{INTRODUCTION}

( n studying the literature on critical thinking, we have encountered some important inadequacies. First, there is the unresolved split between those who theorize critical thinking as a body of reasoning skills to be applied to evaluating arguments, and others who conceive critical thinking as also involving dispositions and affective responses that lead toward moral agency. Clearly, work toward a synthesis of these theoretical perspectives would be desirable. Bensley (2008) noted that some theorists and researchers now agree that critical thinkers need dispositions, such as open-mindedness and fair-mindedness, as well as appropriate skills and strategies. This apparent conflict could be resolved, we believe, if theories of critical thinking were informed by recent research in neuroscience. Neuroscientist Damasio (1994, 2003), for example, argued that the body and the emotions are integral to all thinking. He made the important point that reason requires emotion as an engine (Damasio, 2003). Gallo (1994) agreed that affect and cognition are inextricably intertwined. Linguists Lakoff and Johnson (1999), in their work on the role of metaphor in thinking, suggested persuasively that there really is no such thing as abstract thought. All thought is grounded in bodily and emotional experiences. Secondly, we have found very few accounts of efforts to encourage critical thinking in specific academic courses. That is a lack that we propose to address here, because we are convinced that thinking cannot be divorced from its content, and that some disciplinary content areas are more promising than others for motivating critical thinking. Finally, we feel the need for an account of both the developmental dimensions of critical thinking and the issue of motivation. We believe that, although the capacity to think critically seems to arrive normally at a certain developmental stage, using that capacity is a matter of development in a different sense. We, like many of our colleagues in various disciplines, believe that individuals with the capacity to become critical thinkers should do so. It is imperative to persuade students that they can and should think critically, and we must move them toward the motivation to do so. Education for critical thinking is necessary for full, appropriate development in the contemporary world. 


\section{CRITICAL THINKING THEORISTS}

Piaget's theory of cognitive development (1952) has had a great impact on the study of cognition. Piaget proposed that all individuals pass through four stages of cognitive development. According to Piaget, not only does the quantity of information the individual can absorb increase at each stage, but also the quality of knowledge and understanding improves. The last stage in Piaget's theory is the formal operations stage, which is achieved in adolescence. At this stage, individuals are able to consider a variety of abstract possibilities; they can consider problems in abstract, context-independent, rather than in concrete, terms. They are also able to use formal reasoning, starting with a general theory about what causes a certain outcome, and then deducing explanations for particular occurrences. Some critics of Piaget's theory have argued that formal operations are not the epitome of thinking and that more sophisticated forms emerge in early adulthood (Feldman, 2009). It seems that the most authentically mature thinking involves operations and dispositions not necessarily implied by Piaget's formal operations stage. Our research, as well as our pedagogical practice, has convinced us that context-independent thinking is neither possible nor desirable. In her reflections on the vital role of empathy in sound thinking, Gallo (1994) agreed that context-free abstraction is not a constructive model. It cannot account for or provide motivation. Elder and Paul (2009) made a point that is pertinent here: thinking must be grounded in and oriented toward life experiences.

Developmental psychologist Labouvie-Vief (2006) argued that, as our society becomes more and more complex, individuals need to think in ways that go beyond formal operations. The complexity of our society requires specialization, which makes thinking about issues of general importance more difficult. At the same time, increasing the diversity of the reality to which thought must apply makes generalization hazardous. Finding one's way through this complexity requires thought that goes beyond merely logical thinking to include practical experience, moral judgments, and values (Labouvie-Vief, 2006). Moral judgments and thought about values obviously lie beyond the purview of any particular area of specialization. This strongly suggests that immersion in both multiple disciplines and various cultural traditions is imperative. Labouvie-Vief posited that young adults can learn to weigh all aspects of a situation according to their values and beliefs. They can also learn to see their values and beliefs as contingent: as existing in a human world that includes many different values and beliefs. They can use interpretive processes that allow them to reflect on the idea that real world events and actions are rarely black and white, but must be seen in shades of gray (Labouvie-Vief, 1990). Labouvie-Vief called this more sophisticated thinking postformal thought. Postformal thought goes beyond Piaget's formal operations, which rely on logical thinking processes that conclude with absolutely right and wrong answers. Postformal thought acknowledges that adults encounter situations that need to be understood in relativistic terms. Conclusions are provisional, always subject to further critical thinking. Young adults using postformal thinking are capable of dialectical thought, or of accepting that few issues are clearcut and uncontroversial, and that answers to questions sometimes need to be negotiated. Tolerance of ambivalence, of deferred judgment, of uncertainty, and, in some cases, of endless review and revision, is among young adults' capacities. What can make them aware of the capacity, and what can motivate them to use it? Morton, Worthley, Nitch, Lamberton, Loo, and Testerman (2000) reinforced Labouvie-Vief's major points, noting the increased demands for complex social-cognitive reasoning in the postmodern socio-cultural context.

Sinnott (1998) argued that postformal thinkers shift back and forth from an abstract, ideal solution to a perceived problem and to the constraints encountered in the real world that might inhibit implementation of that solution. Postformal thinkers realize that there can be multiple solutions to a problem, just as there are multiple causes. They also recognize the moral imperative to think about the impact in the world of actually doing what might seem, in theory or in principle, logical. This introduced, not only the moral, but also the social aspect of truly critical thinking. Critical thinking requires, ultimately, engagement with other thinkers. It seems clear that development beyond what Piaget saw as the culmination of natural development is necessary if we are to become critical thinkers and moral agents.

Perry (1980) theorized that young adults can master new ways of understanding the world. He found that students entering college tended to use dualistic thinking in seeing and understanding the world: an action or proposition was either right or wrong, black or white, good or bad. These students tended to be, unequivocally, for or against propositions. If students encounter new, challenging ideas and viewpoints from other students and professors, and from readings and other sources, their dualistic thinking will decline, according to Perry. They begin to see that issues can have more than one plausible "side" and that it is possible for one thinker to hold multiple 
perspectives on an issue. They realize that experts do not have all the answers, and that their own ideas may have validity, if those ideas are tested. According to Perry, at this point they have reached relativistic thinking, or recognizing that different societies, cultures, and individuals could have different standards and values, and that all could have validity. This is also the stage at which students can, and should, begin to develop criteria for judging the validity-or the desirability-of differing viewpoints. It is also at this point that students should take responsibility for stating criteria by which validity can be judged.

As we have noted, an important connection between the issues of development and critical thinking is provided by Elder and Paul (1996). The challenged thinker, as defined by Elder and Paul, is one who has become aware of the actual role of thinking in life and of significant problems caused by unreflective thinking. This is in accord with our experience, but, while Elder and Paul focused on students' thinking about their own thinking, we deal first with thinking in a more general way. History and contemporary society are deeply affected by thinking, much of which is developmentally immature and disastrous. Scriven and Paul (1987) made the crucial point that shoddy thinking is costly. As we have indicated, our approach to fostering critical thinking deals with the issue of motivation to think critically by focusing on the costs of not doing so. Concrete examples, taken from history and from contemporary life, give students opportunities to accumulate information, interpret that information, and see the cognitive distortions (Baron \& Hanna, 1990) in prevalent thinking about the situations in question and to recognize the costly consequences of such thought. We agree with McPeck (1994) that some course content areas are more suitable than others for fostering critical thinking. In the courses we will describe here, we are able to challenge students to think about issues which, because of the content we are dealing with, have significant impact in the social world. Our goal is to move students to recognize that they can, and should, become critical thinkers and that recognizing meaningful challenges is the first developmental step.

\section{CRITICAL THINKING IN A CORE CURRICULUM COURSE}

The first author teaches a general education course that is part of the core curriculum of a small, private university. This course, taught under the rubric of Global and Historical Studies, focuses on modernizing and contemporary Europe. In the author's version of the course, which has other sections taught by a number of professors, egocentric and socio-centric thinking are made explicit themes from the start. Recognizing egocentric and socio-centric thinking and becoming aware of the high costs-the often morally repugnant consequences-of such thinking is a crucial stage on the way to critical thinking. Given the importance of emotional response as a motivator of critical thinking, and considering the emotional impact of what we find morally repugnant, this is a key motivator. In terms of content, this course is ideal as groundwork for the combination of intellectual skill and affective disposition that can become critical thinking.

From Columbus' landing on Hispaniola; through the long history of imperialism, nationalism, and war; to Social Darwinism, racism, and the Holocaust, Europeans' tendency to regard members of other groups as less than human is examined. In fact, this socio-centric thought, which had as one of its consequences or costs the paradox that Europeans both elaborated theories of human rights and denied humanity to peoples they wished to exploit, is central to the course. The failure to think critically and to recognize that empathy is a key component of sound thinking has had spectacularly bad effects in modern European history.

Throughout the course, this issue is looked at in texts, films, and other materials from a variety of disciplines. The consequences of egocentric and socio-centric thinking are evident. The marvelous ideas that originated in modernizing Europe, and the frequent betrayals of those ideas, are a major focus of the course. Students are also made aware that many aspects of modernity, which they have taken to be an entirely positive process, have both an "upside" and a "downside." Finally, the European Union (EU) is evaluated as a deliberate collective attempt to get beyond egocentric and socio-centric thinking and to approach the reality of contemporary international relations in a new way. To a significant degree, the course is about what has happened in response to the modern European idea that progress toward the Good Society is possible.

In this course, I try to move the students toward what Paul (1993) called critical thinking in the "strong sense": toward thinking as and for moral agency. Paul (1993) emphasized seeing the negative consequences of uncritical thought in ethical terms. With this goal in mind, my principal strategy is to challenge students' 
assumptions, to give them the means and the motivation to think about the effects of thinking. We look, first of all, at the role of thinking in the history of early modern and modern Europe. For example, beginning with Columbus and the Spaniards encountering the native inhabitants of Hispaniola, we look at the circumstances in which Europeans have found it morally convenient to define other groups as somehow less than human. This socio-centric tendency-which is not, of course, unique to Europeans-helps to explain how brilliant critical and moral thinking on the part of some Europeans was often betrayed in practice. The ideas of human rights and of universal equality before the law are excellent examples of European Enlightenment thinking. However, other ideas, such as Social Darwinism, and some policies, such as colonialism, impaired the realization of human rights and equality before the law.

Clearly, the quality of thinking has had enormous impact in modern European history and in the histories of other peoples dominated and exploited by Europeans. The costs of uncritical thinking are clear. One of the early readings in this course is Immanuel Kant's essay, "What is Enlightenment?" (as included in Change and Tradition, Global and Historical Studies Program, 2005). In the essay, Kant defined enlightenment as a process of development toward what we call critical thinking. He spoke of it as progress beyond a self-imposed immaturity. This immaturity reflects the laziness and timidity of the unenlightened. The students are thus challenged by Kant's contention that not to think independently is to be immature or underdeveloped, and that becoming enlightened is a moral responsibility. Authorities find it convenient to encourage and exploit immature thinking, Kant argued, but they cannot be held entirely responsible for individuals' failure to become mature. Hostetler (1991) argued that moral agency requires that the agent be able to judge socially accepted norms critically. From the beginning, then, the content of the course makes it possible to see the importance of thinking in history, as well as about history. Later in the course, we read two texts by Vaclav Havel (as included in Change and Tradition, Global and Historical Studies Program, 2005), who, like Kant, denounced moral apathy in the face of pressure from tyrannical authorities. Recognizing, as Havel recommended, when norms are in principle good, but in practice ignored or corrupted, is also required. The costs of failure to mature, or develop, into critical thinkers and moral agents are evoked dramatically by these thinkers.

Between Kant and Havel lies the Holocaust. Justified in part by the pseudo-scientific ideology of Social Darwinism, the Holocaust can be seen as a lethal synthesis of extreme socio-centrism and ruthless logic. Primo Levi (1959) whose Survival in Auschwitz we read in class, characterized this grotesque thinking as "geometrical madness." This is the point in the course at which it becomes most clear that moral repulsion and its emotional/empathic impact are indispensable to truly sound thinking.

Another important theme of the course, which also relates to the issue of thinking, is the corruption of thought by vested interests and identity. It is often noted that critical thinking is most difficult in areas where the thinker has strong vested interests or where his/her investment in identity is at stake. Social Darwinism and nationalism are two productive examples of the ways in which vested interests and investment in identity have operated in modern European history. As we see in looking at the Holocaust, the former is also an example of how the pretense of value-free, scientific thought can be used to rationalize what, to morally engaged thinkers, can only be repugnant. Social Darwinists, following Herbert Spencer's (1898) application to society of the Darwinian explanation of evolution in nature as the result of competition for scarce resources-itself an historically conditioned understanding-argued that some humans are superior and therefore destined to control more resources than others. This view of society had profound influence, on issues ranging from government aid to the poor to colonialism. In the long run, it was used to link the idea of social progress to eugenics and the Holocaust. The pretense that Social Darwinism was scientific provided ideological cover for practices that advanced the interests and glorified the identities of dominant groups. In the course, then, students are challenged to see, not only the fallacies and distortions underlying the ideology, but also its morally unacceptable consequences.

In the case of nationalism, students are challenged to accept that the idea of nationalism-that a "people" is entitled to be governed by its "own" state-is liberating when it inspires people who are living under the domination of an empire, but oppressive when it justifies ethnic cleansing or genocide. Because the American and French revolutions were justified by the idea of nationhood and popular sovereignty, that idea seems morally admirable. Those revolutions, of course, were fought to advance certain interests and to establish and glorify national identities. Those identities have given rise to socio-centric thinking and have justified questionable treatment of other peoples. 
Moreover, in other cases, like the aftermath of communist Yugoslavia's collapse, nationalism has justified attempts to rid a territory of all but a single "people." Looking closely at Social Darwinism and nationalism moves students toward being challenged thinkers in two ways. In the case of nationalism, it moves them toward ambivalence and away from definitive conclusions about the quality of a set of ideas. Seeing the consequences of Social Darwinism and the other ideas to which it is related challenges them to see the morally dubious nature of some ideas which, in their contemporary forms, the students may have agreed with.

The culmination of this course, and the students' best opportunities to practice critical thinking in an area where they have vested interests and identity investment, come at the end, when we read T. R. Reid's The United States of Europe (2004). Having looked at the EU as Europe's attempt to overcome the consequences of centuries of socio-centric thinking, and to realize the promise inherent in Europe's best ideas, we read and evaluate Reid's argument that the EU is, in many ways, superior to the Unites States and destined to replace the US as the world's moral and economic leader. This debate is understood in the context of the idea of progress toward the Good Society. Like a number of other scholars and commentators, Reid emphasized Europe's choice to develop and exercise "soft power," as opposed to the hard, military power possessed and exercised by the US. Reid also argued that the EU, by many measures, provides a better life for its citizens than does the US. Most students reflexively reject Reid's comparison and give ready-made reasons for doing so. They tend to repeat assertions that have long been in the air: the assertion that the US has "the best health care system in the world," for example. As their culminating assignment for the course, however, the students are challenged to write an essay, including a reflection section, in which they present and argue for criteria by which to judge societies-by which to identify the good, or at least a better, society-and then present evidence related to those criteria. Criteria such as life expectancy, healthy life expectancy, infant mortality, diversity, policies for supporting families, voter enfranchisement, gender equity, and others have typically been presented by students. Having chosen such criteria for judging the quality of societies, they are in a position to look at and evaluate the wealth of relevant information that is readily available. Most students are surprised to find the US well behind most EU members on indices that they, the students, have chosen as most important. Both the philosophical choice of criteria and the search for information relevant to those criteria are key components of real critical thinking. Moral agency is also involved, since the issue is defining the Good Society. The students have thought critically about the values that ought to dominate thinking about society and the problems that ought to be solved. In the process, they have gone far beyond reflexive defense of their own identity and interests. They have recognized that emotion can play both a positive and a negative role in thinking. In fact, some, in their reflection paragraphs, recognize that they ought to identify themselves as critical thinkers, not as members of any group. They have clearly gone beyond the unreflective stage and become, at the minimum, challenged thinkers.

\section{CRITICAL THINKING IN A HUMAN DEVELOPMENT COURSE}

The second author teaches psychology courses at a large, urban, public institution in the Midwest. The author teaches Child Development and Educational Psychology courses. The content of the courses is ideal for exploring ideas and sharing impressions. One key to encouraging students to think independently and critically is to create a classroom culture that fosters engagement in critical self-reflection as they consider where their views and impressions may have originated. One educational objective I had was to encourage students, in as many ways as possible, to look critically at their own opinions and assumptions. Moving from being unchallenged, unreflective thinkers is a continual process of being challenged by new information and finding oneself in a place in which one has to evaluate current knowledge before moving on to gain new knowledge. Halpern (2003) advocated a skills approach to critical thinking, which allows thinkers to reach a number of goals, including testing hypotheses, thinking under uncertainty, making decisions, developing problem-solving skills, and thinking creatively. I wanted to encourage development of these skills, while going beyond the mere application of thinking skills to foster dispositions like empathy that are vital to moral agency. Instructors should want students to be able to examine relationships, construct arguments, respect diverse perspectives, view ideas and problems from different points of view, and have the flexibility to change their thinking when presented with irrefutable evidence (MacKnight, 2000). In addition, thinkers should be able to respond to the emotional impact of problems and incorporate that emotional impact in their thinking. 
Students came to the class with many assumptions and opinions about issues explored in the Child Development course. One way in which I challenged students in this course to move from being "unreflective" thinkers to being "challenged" thinkers was to create an assignment in which they would learn new information that was incompatible with their current assumptions. I assigned students in my Child Development class the following exercise: "Although the United States is one of the richest countries in the world, we still have one of the highest infant mortality rates. Find three websites with information about why the US is so far behind other industrialized nations in keeping our infants alive. Include three possible changes we, as a nation, could make that would reduce infant mortality rates. Write a 500-1000 word essay in which you summarize three reasons for our high infant mortality rate and three strategies we, as a nation, might use to improve it."

Unreflective thinkers, according to Elder and Paul (1996), are unaware of the determining role that thinking plays in their lives and of the many ways their egocentric or socio-centric thinking is causing problems. My challenge as an instructor was to move students from being unreflective thinkers to becoming challenged thinkers. Thought provoking questions required that students go beyond facts and use knowledge in the exercise of judgment that might lead to action. Critical thinking questions tended to generate more questions and engaged students in thinking about their thinking. One way I helped students move from the first stage of Elder and Paul's stage theory of critical thinking was to have them explore articles they had researched regarding infant mortality in the United States as compared with other countries. Infant mortality is an issue with definite emotional impact. Infant mortality was defined as the number of deaths in the first year of life per 1,000 live births, which is an index used around the world to assess the overall health of a nation's children. Specifically, I wanted students to learn how US infant mortality rates compared with those of other nations.' What were some contributing factors in infant mortality? Students were to find as much information as possible regarding cultural differences, health care options available to moms, socio-economic differences in infant mortality, and overall health of the mother. They discovered that poverty and weak health care programs for mothers and young children are mostly responsible for infant mortality. In the US, nearly $10 \%$ of low-income minority mothers, and nearly $30 \%$ of adolescent mothers, receive inadequate prenatal care, and some receive no healthcare at all. Many students reported being astonished that mothers in other countries received many more weeks of paid maternity leave than mothers in the US, who receive up to 12 weeks of unpaid leave. Additionally, they learned that the countries that outrank the US in infant survival rates provided all their citizens with government-sponsored healthcare benefits. Students began to move from their unreflective way of thinking to more critical thinking when they were challenged by their findings. Students reported being forced to think about their inferences and assumptions based on the new information they had gathered. They discovered that the US was one of the richest countries in the world, but was not even on the list of the top 20 industrialized nations for healthy babies. Most students reported never really giving infant mortality rates much thought at all. Once they had read the articles, they realized that the United States' infant mortality rates were among the highest in the world, regardless of the fact that the US is one of the most industrialized nations.

Once students became aware of the extent of infant mortality, they began to realize that there was a problem in their thinking. As Elder and Paul (1996) pointed out, challenged thinkers, unlike unreflective thinkers, are becoming aware of how they think and of how the quality of thinking affects their lives. They reach an awareness that critical, morally significant thinking requires them to reflect about their thinking, as well as about thinking in general. The students in this class began to recognize that their own thinking might be flawed and that the flaws might be barriers to development. Generally, egocentric and unchallenged or unreflective thinkers lack the knowledge that critical thinking requires practice in taking thinking apart and actively improving it. Such underdeveloped thinkers were also unaware that not thinking critically may have allowed them to drift into accepting actions or situations which, once they had begun to think about them, were morally repugnant to them.

To further expand students' thinking, I had them form groups of four to explore possible reasons for the US's high infant mortality rates and what we, as a nation, could do about it. The culmination of the assignment was to have students write a reflection paper describing the process by which their thinking was changed. Students' reflections described how they assumed that, since the US was one of the richest nations, infant mortality, and healthcare in general, were not a problem. While working in groups, students discussed ideas about what could be done to improve the infant mortality rates, such as providing better healthcare access for pregnant women so they could get early prenatal care, instead of not going to see a healthcare provider at all, or waiting until the last trimester. Also, students stated that the US would benefit from better education about birth control options; habits 
such as smoking, drinking alcohol, and drug use that are harmful to infants in utero; and the benefits of breast feeding infants. Students stated they found this a valuable exercise and it changed their way of thinking in that they would try to recognize when they might be making erroneous assumptions. Their pride in being Americans, and their emotional investment in that pride, helped to motivate the changes in their thinking.

\section{CONCLUSION}

Challenged thinkers become aware of thinking as such and of the role of thinking in their lives. They realize that significant thinking requires reflection and active seeking of information. It is important for instructors to lead class discussions about the thinking process and to foster, collectively, thinking through a problem aloud. Instructors should design classroom activities that require students to think about their thinking. As students in my Child Development class wrote in their reflection papers at the end of the exercise, they were beginning to understand the role of egocentric and socio-centric thinking in human life. Students need to be encouraged to utilize their challenged thinking in other areas.

Our recent research and our continuing pedagogical practice have persuaded us that the issue of motivation is crucial to critical thinking and that acknowledging the emotional component of all thought is a key to motivation. It is important that students recognize that they have the capacity to think critically and that the quality of thought is an important factor in their lives and in their collective histories. Recognizing the enormous costs of uncritical thought is a vital developmental stage and plays a role in motivation. We are convinced, however, that the merely intellectual recognition of these costs is inadequate. Damasio (2003) argued that emotion is the engine of the thinking process. Awareness of the cost of unsound thinking has emotional impact on students and helps motivate efforts to think more critically. The capacity for moral repugnance at these costs should be an explicit theme of courses aiming to foster truly critical thought.

\section{AUTHOR INFORMATION}

Larry W. Riggs earned his doctorate at the University of California, Santa Barbara. He is Professor of French and Interdisciplinary Global and Historical Studies at Butler University. Dr. Riggs is the author of books and essays on literary subjects ranging from Montaigne to Kafka, and on cultural studies, literary theory, cinema, and, most recently, transformational learning, critical thinking, diversity, and sociocentric/ethnocentric thought. With his coauthor, Dr. Sandra Hellyer-Riggs, Dr. Riggs has written articles and presentations on many aspects of critical thinking pedagogy.

Sandra Hellyer-Riggs earned her doctorate in Higher Education from Indiana University. She is currently teaching in the Psychology Department at Indiana University-Purdue University at Indianapolis. She teaches Developmental Psychology, Tests and Measurements, and Behavioral Analysis. Her research interests are student diversity, critical thinking, transformational learning, and sociocentric/ethnocentric thought. Dr. Hellyer-Riggs and co-author Dr. Larry Riggs have written many articles on critical and ethnocentric thinking. Dr. Hellyer-Riggs has presented papers at national and International conferences in her fields of expertise. E-mail: shellyer@iupui.edu (Corresponding author)

\section{REFERENCES}

1. Baron, P., \& Hanna, J. (1990). Egocentrism and depressive symptomatology in young adults. Social Behavior and Personality, 18(2), 279-286.

2. Bensley, D. (2008). Thinking critically about critical thinking approaches: Comment on Yancher, Slife, and Warne. Review of General Psychology, 13(3), 275-277.

3. Damasio, A. (1994). Descartes' error: Emotion, reason, and the human brain. New York, NY: Penguin.

4. Damasio, A. (2003). Looking for Spinoza: Joy, sorrow, and the feeling brain. New York, NY: Harcourt.

5. Elder, L., \& Paul, R. (1996). Critical thinking: A stage theory of critical thinking. Journal of Developmental Education, 20(1), 34-35.

6. Elder, L., \& Paul, R. (2009). Becoming a critic of your thinking. Retrieved from http://www.criticalthinking.org/pages/becoming-a-critic-of-your-thinking/478 
7. Feldman, R. (2009). Discovering the life span. Upper Saddle River, NJ: Pearson Prentice Hall.

8. Gallo, D. (1994). Educating for empathy, reason, and imagination. In K. S. Walters (Ed.), Rethinking reason: New perspectives in critical thinking (pp. 44-60). Albany, NY: State University of New York Press.

9. Global and Historical Studies Program, Butler University. (2005). Change and tradition: Revolutionary Europe and colonial Nigeria. Upper Saddle River, NJ: Pearson Custom Publishing.

10. Halpern, D. (2003). Knowledge and thought: An introduction to critical thinking. Hillsdale, NJ: Lawrence Erlbaum.

11. Hostetler, K. (1991). Community and neutrality in critical thought: A non-objectivist view on the conduct and teaching of critical thinking. Educational Theory, 41(1), 1-12.

12. Labouvie-Vief, G. (2006). Emerging structures of adult thought. In J. J. Arnett \& J. L. Tanner (Eds.), Emerging adults in America: Coming of age in the $21^{\text {st }}$ century (pp. 59-84). Washington, DC: American Psychological Association.

13. Labouvie-Vief, G. (1990). Emerging structures of adult thought. Adult development (V2): Models and methods in the study of adolescent and adult thought. New York, NY: Praeger.

14. Lakoff, G., \& Johnson, M. (1999). Philosophy in the flesh: The embodied mind and its challenges to Western thought. New York, NY: Basic Books.

15. Levi, P. (1959). Survival in Auschwitz. New York, NY: Collier.

16. MacKnight, C. (2000). Teaching critical thinking through online discussions. Educause Quarterly, 23(4), 38-41.

17. McPeck, J. (1994). Critical thinking and the "trivial pursuit" theory of knowledge. In Kerry Walters (Ed.), Rethinking reason: New perspectives in critical thinking (pp. 101-117). Albany, NY: State University of New York Press.

18. Morton, K., Worthley, J., Nitch, S., Lamberton, H., Loo, L., \& Testerman, J. (2000). Integration of cognition and emotion: A postformal operations model of physician-patient interaction. Journal of Adult Development, 7(3), 151-152.

19. Paul, R. (1993). Critical thinking: What every person needs to survive in a rapidly changing world. Dillon Beach, CA: Foundation for Critical Thinking.

20. Perry, W. (1970). Forms of intellectual and ethical development in the college years: A scheme. New York, NY: Holt, Rinehart and Winston.

21. Piaget, J. (1952). The origins of intelligence in children. New York, NY: International Universities Press.

22. Reid, T. R. (2004). The United States of Europe. New York, NY: Penguin Press.

23. Scriven, M. \& Paul, R. (1987). Defining critical thinking. Retrieved from http://www.criticalthinking.org/pages/defining-critical-thinking/766

24. Sinnott, J. (1998). The development of logic in adulthood: Postformal thought and its applications. New York NY: Plenum.

25. Spencer, H. (1898). Principles of biology. New York, NY: D. Appleton \& Company. 